THE INOCULATION, PROPAGATION AND PRESERVATION OF THE VIRUS OF ANIMAL VACCINE. WITH A DESCRIPTION OF THE APPEARANCES OF KINE POX, AND DEMONSTRA'TION OF THE VACCINE VESICLE UPON HEIFERS. ${ }^{1}$

BY S. C. MARTIN, M.D., OF ROXBURY.

WheN, in response to an invitation by your secretary, gentlemen, received a short time since, I promised to address this society upon the subject of animal vaccination, I had in contemplation merely the preparation and reading of a paper upon that subject. Afterwards, however, at his earnest solicitation, and because, on reflection, I appreciated that it would serve to usefully supplement and illustrate my remarks, I decided to present for your inspection tonight an animal at present undergoing the disease. I trust that the opportunity I am thus able to afford you of observing the appearance of cow pox, as artificially produced, will be productive of sufficient interest to you, to warrant the very considerable trouble and inconvenience which this has necessarily caused me. I will allude to this animal later on.

I do not propose to treat you to any extended remarks in regard to the comparison of vaccinia produced by heifer-transmitted virus, and that from the human subject after many years transmission from arm to arm, that is, humanized virus. This subject has been fully and convincingly presented to the profession by my late father, in his Report on Animal Vaccination, made to the American Medical Association in 1877 , and published in the transactions of that year; and abroad by Bousquet, Steinbrenner, Estlin, and a host of others. Those of you who were in practice fifteen years ago, and tried the experiment which my father urged upon all, of vaccinating a child upon one arm with the old humanized virus, and upon the other with the cow-pox of Beaugency, and watched the progress of the vesicles on the two arms throughout their entire course, certainly do not need to have the differences described. It is no longer possible here to observe the effects of long-humanized virus. There is probably now none of it in the country; that which passes under that name being but a few human removes from the cow. Which of the two forms of the disease would $\grave{a}$ priori appear, and has shown itself to be, the better protection against small-pox, is to my mind, a matter upon which there is no room for difference of opinion. I have here for your inspection the very interesting plates of Bousquet and Decanteleu, illustrating most clearly the differences in the action of the long-humanized and original cow-pox virus.

Before entering upon the more practical part of my remarks, it is important to define just what true animal vaccination is. I know of no better definition than that by my father: "The inoculation of a young selected animal of the bovine species from an original spontaneous case of cow-pox, from this others, and so on, in continuous and endless series, as the source and the only source of virus for the protection of the human race against variolous disease." This alone is true animal vaccination. Retro-vaccination, or the inoculation of animals with humanized virus, is an entirely different matter and has nothing to recommend it. 1 Read before the Section for Clinical Medicine, Pathology and Hy-
giene of the Suffolk District Medical Society, November 11, 1885.
A few words in regard to some of the various stocks of cow-pox. On March 28, 1866, the famous case at Beaugency, France, was discovered. From virus derived from inoculation from this, Professor Depaul continued the propagation of animal virus at Paris, under the auspices of the Academy of Medicine. 'This was the stock introduced into this country by my father in 1870. Various other cases of spontaneous cow-pox have been discovered from time to time in Europe, with virus from which animal vaccination has been and is still carried on in a number of establishments, notably at Brussels, Amsterdam, Rotterdam and the Hague.

After the first experinental inoculation of two calves, animal vaccination was not carried on at Beaugency, but was immediately transferred to Paris, and to that city the practice of the method in France was confined. A knowledge of this fact may, perhaps, in the future prevent a repetition of the ludicrous mistakes which we occasionally see in print, that various individuals have from time to time imported animal virus into this country from Beaugency.

When in Paris in 1873, my father was assured by Professor Depaul that the Beaugency virus, sent to him in 1870, was the last which left the city before the siege in that year, and that during the siege, the "stock" was lost. The animal virus employed since the Franco-Prussian war, is from other stocks, discovered since that of Beaugency.

In February, 1881, a case of suspected cow-pox was reported to this society by Dr. E. W. Cushing, and was immediately referred to my father, who accompanied Dr. Cushing to his brother's farm at Cohasset. He there found several cows suffering from an eruption on their teats and udders. With virus from these, my father and myself inoculated several animals as well as children, obtaining undoubted typical vaccinal effect. This stock I have continued uninterruptedly since, and, as far as 1 know, it is the only authentic case of cow-pox in this country which has been preserved.

I keep up three different stocks continuously, namely, the Beaugency, Cohasset, and the Esneaux stock imported from Dr. Warlomont of Brussels ; reserving the upper flank of the animal for the Cohasset, the lower flank for the Belgian, and the belly for the Beaugency, thus keeping the three stocks entirely distinct, and issuing the virus from all indifferently. They appear to be all equally typical in appearance and results.

It goes without saying that the animal to be vaccinated should be in perfect health and condition. This must be preserved by proper sanitary measures not necessary to detail here. The animals should be from six to eighteen months old. Too young animals are troublesome to care for and manage, and those too old and large are not only difficult to control, but, notably in the case of those which have borne calves, are probably not free from danger of tuberculosis. I use bulls and heifers indifferently. The animal is secured upon the operating table in the same manner as the one now before you. Portions of the flanks and belly are cleanly shaved, as you observe. Scarifications are then made in precisely the same manner as in the human subject, not deep, but merely sufficient to produce a slight appearance of serum tinged with blood. These I make some three-quarters of an inch by half an inch in size, and place them at intervals of at least 
an inch and a half apart. The fluid virus taken directly from an animal, in which the disease has matured and lying upon an arjoining table, is then thoroughly rubbed into these scarifications. The disease matures at about the seventh day. In this, however. experience and careful inspection of the vesicles is necessary to determine the precise time, it depending somewhat on the condition of the animal and climatic influences. During the progress of the disease, the animal is but little affected, the temperature rarely rising more than two or three degrees. Occasionally in a very fine development of the disease, the animal may lose its appetite for a day or two.

The vesicle on being opened, is wiped clean of any blood or pus, and gentle pressure is then applied. The fluid contained in the vesicle is of a light amber color, and should have an unctuous, smooth character. In animals where the disease is accompanied by excessive action, as shown by much tumefaction of the surround. ing tissues, a large amount of thin, almost colorless fluid is poured out, due to an admixture of an excessive flow of serum with the virus itself. I shall allude to this matter more at length in a moment. In some calves, from the finest vesicles it is impossible to obtain lymph without a certain tinge of color, due to the admixture of a minute quantity of blood. This, it can be readily seen, is not of the slightest importance in virus taken from the animal. It was always my father's custom, and is my own, to use those points most tinged, not only for vaccinating other animals, but also for human vaccinations. The sharp end of the ivory points is charged on both sides with the fluid virus as it exudes from the vesicle. When dried, the points are wrapped in cotton in packages of convenient size, then in paper, and finally, are hermetically sealed in gutta-percha tissue.

This effectually guards against moisture, and if care is taken to keep them cool as well, they will retain their efficacy for a considerable time. I have myself made vaccinations with points so kept for over a year, and have obtained perfectly good and typical results. This, however, is not recommended. Points should be ordered only in small quantities as required, and used within a few days or weeks. In this, and also in all the details of propagation, it is not what may perhaps suffice, but what experience has shown is safe and good beyond peradventure.

As to the form of virus, I recommend nothing but fluid lymph dried upon ivory points, prepared as above described. Crusts are liable to prove inert, and, unless used with the greatest care, may cause very bad results from partial decomposition ensuing after the crust has been moistened. 'They are apt also to encourage highly undesirable methods, such as inserting the dry, pulverized crust, or portions of the crust itself into punctures; also mixing with water, and allowing the mixture to remain too long exposed to the air. 'This was one very serious objection to the "solid lymph cones," formerly sold in large quantities, but now it is believed, no longer in the market. These were composed of crusts and fragments of crusts, powdered, moistened, and molded into cone-shaped masses. They were not only open to all the objections applying to crusts, but the mode of their manufacture rendered them peculiarly liable to dangers evident to any intelligent physician. Storing fluid lymph in glass capillary tubes has been found very unsatisfactory. It was at one time much in vogue, but experience has shown that virus so stored is extremely liable to prove inert, and unless sealed perfectly tightly, may become decomposed and dangerous. One great merit of points is, that it is well nigh impossible to have serious complications attending their use, if they are charged with pure, active lymph in the first instance. They either produce typical vaccinia, or, at the worst, prove inert owing to some accidental cause subsequent to charging. In distributing any form of virus, we must bear in mind that among so large a body of men as compose the medical profession, some will be found who will not use proper care on all occasions, and it is most important to issue only that form with which it is impossible to go wrong.

The propagation of animal virus, and its distribution to physicians, are at present, in several ways, in an unsatisfactory state. The New York Medical Record, in its issue of October 24th, 1885, editorially says : "At present in all large centres, bovine virus in vaccinating is mainly used, and the steadily increasing demand for this, has led to the formation of companies who undertake to cultivate and sell it, with a view primarily, to making money. These companies are not, as a rule, under any official supervision, and are at perfect liberty to disseminate worthless crusts or septic poison among the people. We learn, as an illustration, that, with a lot of bovine virus recently sent to Montreal, there were one hundred and two trials and one hundred and two failures, while other specimens have produced badly inflamed arms. Here, surely, is a most anomalous condition of things. It is apparent at once that the cultivation and selling of virus should always be under some official supervision. Most States indirectly compel the vaccination of children, and they should in all justice, see that this vaccination be made with pure and efficient material. But the public supervision of vaccine companies is not yet carried out as it should be, although it is a measure most imperatively needed for the security of the people."

The suggestion is most timely, and I hope it may some day be properly carried out. An attempt at an examination and report upon the various propagating establishments was made in 1882 by the National Board of Health, but was productive of no marked beneficial result. Some of the men detailed for the duty of examination were ludicrously incompetent, their reports showing on their face an ignorance of even the elements of the subject. The only efficient examination and report of which I have any knowledge, was made by the private enterprise of the Medical News of Philadelphia. Dr. W. M. Welch, of Philadelphia, the well-known writer and authority on small-pox and vaccination, was employed for the task, and the results were published in the numbers of the Medical News from April 15th to May 27th, inclusive, 1882.

Great commercial competition has arisen in the matter of supplying animal virus. The country is flooded with circulars, frequently illustrated with heads of heifers, and gentlemen in spectacles vaccinating calves, or adorned with fanciful mottoes, such as "National Standard" and the like. One ingenious propagator advertises that his virus was imported direct from the "vast herds of the Duke of Beaugency," doubtless a bucolic French noble, who, it is believed, thus appears in history for the first time.

Seriously, gentlemen, this does not show a promising condition of things. A regular physician, agent for the sale of vaccine virus, in a recent number of the 
Boston Medical and Surgical Journal, after saying that he does not know whether the propagator for whom he is agent is a physician or not, but does know that he is a liberal business man, continues, "Animal vaccination and the supply of vaccine virus is a business or trade. There is no mystery about it, etc., etc." I trust, and am sure, that this is not the prevailing opinion among the profession. I desire most earnestly and emphatically to record my protest against such views. The advertising and puffing of vaccine virus, as too often carried on, is a " business or trade," and a pretty low one at that ; but I insist and reiterate that the propagation of animal virus, worthy of the name, requires accurate professional knowledge, long experience, the utmost care, and I may add, honesty.

The distribution of virus to physicians is now largely done through druggists and instrument makers. My father and myself for several years refused to supply virus except directly to physicians, or through the hands of local agents in Boston for the convenience of the profession. We continued this rule until it became evident that physicians would not take the trouble to procure it direct, but preferred to rely on the nearest druggist. This is all wrong. Vaccine virus is not a substance to pass through three or four intermediate hands before reaching the physician. It is peculiarly liable to deterioration, and, furthermore, the physician should know just who propagates the virus he uses. I fear that in many cases, he is entirely in the dark as to this. Many propagators do not do business under their own names. Large numbers of "Companies" are advertising widely. Possibly, some of these are regularly incorporated companies and are conducted by competent men; but it is believed that some of them adopt the title merely as a convenient nom de guerre, like those of certain "Institutes" composed of a "Board of Physicians," in whose spacious laboratories skilled chemists and savans compound precious elixirs for the relief of noble but erring youths. I wish to emphasize this matter somewhat for the reason that physicians have become far to careless as to the source of their vaccine supply. The druggist naturally will sell the virus on which he can make the most profit. Animal virus, properly and honestly propagated, is not cheap. By improper methods it can be produced in immense quantities. The temptation to do this, particularly in times of great demand, is irresistible to men who have no professional reputation to sustain, and who look upon the matter as a "business or trade."

Let me call attention to a case which has come to my notice. Dr. - , a reputable and competent propagator in the West, and whose virus had become identified with the name of the town where he lived, had the following experience : -

A homœopathic physician came to the town, assumed the name of the - Vaccine Co., and secured a powerful drug-house as his agents. He propagated no virus himself but gave to a number of ignorant farmers in the neighborhood, two cents a point for charging the points with some sort of fluid, which they managed to get from their calves. It 'being in a time of great demand, these points were sold in great quantities by his agents, as virus from the town named. They naturally produced far from satisfactory results, and much of the blame fell upon Dr. $\_$: physicians supposing it to be his virus. He exposed the fraud in the local paper. The selling agents of the "Company" threatened him with a suit for heavy damages, but on investigation concluded to let the matter drop, and to close their connection with the "Company" in question.

The above is a good illustration of the propagation of virus as a "business or trade."

I have described and shown you what I consider the proper method of inoculating the animal and preparing the virus. My father and myself after many experiments, found it to be the best. The number of points which an animal vaccinated in this manner, will yield, is comparatively small; but $I$ consider that any attempt to increase the yield is fraught with certain dangers. In times of great demand (the time above all when only what is known to be the best should be practiced) certain propagators have found this method far too old-fashioned and " unbusinesslike" for their views. An animal must be made to yield 15,000 to 20,000 points, or more. To accomplish this the following expedient has been adopted. A full-grown cow is usually selected on account of its size. Scarifications from two and one-half to three inches in length by some two to three inches in width are made on the flanks at intervals of about an inch apart. These produce large inflamed surfaces, often coalescing, so that at the end of seven days, one large sore will often occupy the whole escutcheon of the animal. Upon this being opened, an immense flow of colorless fluid results, with which points are charged. I state the method to you, and say frankly that I utterly disapprove of it. Such extensive scarifications with the great attendant inflammation, must necessarily produce an excessive flow of serum, and it would be a bold man indeed, who would confidently pronounce the resulting fluid free from the products of inflammation. It will readily be seen that such immense sores will yield an almost unlimited supply of this fluid. It seems to me that the practice is fraught with dangers, evident to any intelligent physician. Suppose the only possible trouble to be apprehended from such virus was either failure to produce typical vaccinia, or the production of vaccinia, plus a certain amount of inflammatory action, greater or less.

Surely, there being a better way, it should be practiced in preference, even if not so profitable, and even if it did not allow the propagator to be so "liberal" to agents and boards of health.

The wholesale propagation and distribution of improperly prepared virus, have done infinite harm to the reputation of animal vaccination. My father introduced the method as an improvement on the existing state of things. It is an improvement, and a great reform, if properly and honestly carried on ; but many reports, a few of which I read to you, tend to show that from certain causes it is capable of becoming the very reverse of a reform.

The Board of Health of Louisiana writes, May 16, 1882:

"Failure with bovine points during the present season has been the rule rather than the exception."

The Secretary of the State Board of Health of Arkansas writes, April 28, 1882 :-

"'The trouble in this State has been not so much from the bad effects derived from bovine virus, but rather, from obtaining no effects at all. Reports have reached me from all parts of the State in regard to the worthless character of much of the bovine virus employed." 
The Secretary of the Medical Association of Ala- oped by which in the future the profession may be bama, writes, April 30, 1882 :-

"To sum up the whole in brief, the profession here to a man, prefer humanized virus to the bovine lymph in any form, and have long since abandoned it."

The State Board of Health of Minnesota, writes, April 28, 1882:-

"There has been much complaint in all directions."

Dr. E. L. Griffin, of Fond du Lac, Mich., an intelligent and able propagator of virus, writes, February 8 , 1882:-

"I fully sympathize with your views on what is being done during the boom to supply the demand, and greatly fear that animal vaccination will get a bad set-back from the experience of this season."

The same gentleman writes, March 6, 1882 :-

"'Those infernal 'cones' have done infinite mischief, I believe, in the West. The other day I got a sharp letter from the Secretary of the Board of Health of a neighboring city, upbraiding me on the quality of my virus, saying that it did not give typical developments of pock, but produced enormous sloughs and sore arms, etc., and wished to know what I was going to do about it. Upon inquiry by correspondence, I found that they had been using cones, obtained from a druggist in Chicago, and that the stuff was represented as coming from me."

Dr. D. A. McLean, of Stanton, Mich., writes, May 8, 1882 , in regard to his experience with points from the notable vaccine company before referred to, whose virus was propagated by farmers. This virus he procured through a druggist, supposing it to be that propagated by the gentleman who exposed the fraud, as narrated before. Dr. McLean writes : -

"The remaining 1,400 cases were vaccinated with points obtained from that institution. A large proportion of these cases were very severe, the fever high and very frequently confining them to the house for a week or more. The local manifestations were great swelling, redness, pain, in fact all the symptoms of vaccinia greatly intensified, and frequently resulting in a deep, foul, and very offensive ulcer. These were very slow to heal; in fact, at this date, nearly three months after the vaccination, I am told that some are not healed. In a large number of cases, I am satisfied that no true vaccine pustule was formed, merely a septic sore, and these were the worst cases to heal, and the constitutional disturbances were the greatest. From ny experience I am led to believe that the virus was not pure, that is, proper care had not been used in propagating and preparing it; that pus from ordinary suppurating sores had been used to charge the points, or at least, had become mixed with the vaccine virus."

Dr. Benj. McCluer, of Dubuque, Iowa, writes, July $7,1882:-$

"I used one 'cone' during my vaccinations last December and January. I became fearful of them, as also of the points. The vaccinations were so severe in development, such immense ulcerations occurred in apparently healthy children, that I became doubtful in regard to the propriety of vaccination at all. In fact I lost all confidence in the integrity of the parties dealing in vaccine matter, and felt that they were actually trifling with the health and lives of the community, as well as the character and honor of the profession which was procuring the supply of vaccine matter from them. I do hope that some way may be devel-

able to secure pure vaccine."

Dr. John B. Weston, of Chester, Pa., writes, October $6,1882:-$

" Part of the time I used a cone which came in a metal box with a file. Part of the time I used a crust. My experience with the cone was vexatious in the extreme. Erysipelas was not infrequent, and I am afraid that the fever and disturbance in one case, if not in two, caused a child's death. The sores in most cases were horrible, and many told me that they would rather have variola itself than what they had gone through. It was not due to any carelessness on my part, for I did not use any a second time, or mix one day's filings with another, so I know the fault was not mine."

Dr. T. S. Hopkins, of Thomasville, Ga., writes to the National Board of Health Bulletin of March 4, 1882 , describing the effects of vaccination with virus in the form of "cones": -

"The result has been fearful. Nearly every one vaccinated has suffered severely from erythema, or erysipelas, the arm swollen from shoulder to wrist, and the point of puncture presenting the appearance of a sloughing ulcer discharging freely sanious pus. Many of the cases have been confined to bed with high fever from five to ten days, requiring the constant application of poultices, and the free use of morphia for the relief of pain. It (the virus) 'takes' in all cases, regardless of previous vaccination as shown by wellpitted mark, and the inflammation begins frequently on the second day. Those who have tried it tell me they would much prefer to have small-pox."

I have reports of many more similar groups of cases. but will not prolong my quotations to a tedious length. The above are merely selected as being well-marked instances, showing clearly the symptoms of septic poisoning in a greater or less degree. It will be observed that the above are groups of cases, showing precisely similar symptoms in a large proportion of the persons vaccinated.

Single isolated cases of even severe complications, the result of accident, or in unsound or sickly subjects, prove nothing; but such instances as given above are uninistakable.

The vaccinia, induced by heifer transmitted virus, is characterized by a certain intensity of action which might be startling to one accustomed to seeing only the effects of the enfeebled virus of long humanization; but this intensity is not to be deplored, and is only what is necessary for proper protection against variola. It should run a regular course, the vesicle should not break down except through exposure to violence, and, finally, the crust should fall, leaving a healthy, thoroughly healed cicatrix.

In speaking of these various abuses, being a propagator of vaccine virus, I am placed in a somewhat delicate position, and one in which my motives may be easily misunderstood and wilfully misrepresented; but I should be remiss in my duty if I did not present to your notice, as forcibly as I can, the matter of all others connected with my subject, which has to-day become of the most vital practical importance to the profession.

My father having introduced the method into this country, and having advocated it through good and evil report, stands in relation to it very much as Waterhouse, in earlier days, did to vaccination. Any 
failure or complications attending it are indirectly laid to his charge.

The complications spoken of above, as well as the woful lack of success, are not due to the practice, but to the malpractice of animal vaccination. With animal virus properly and honestly propagated, the chances of failure or serious complications are exceedingly small.

Practically the only guarantee which the physician has that the substance on the end of an ivory point is pure virus, or indeed, that it is vaccine virus at all, is the reputation, skill and honesty of the propagator. So long as physicians and boards of health will buy, and recommend virus simply because it is cheap and produces a "sore arm," utterly regardless of the source of supply, or whether the propagator is a physician or not, so long may we expect a reckless increase in production, the keenest and most dishonest competition, and such results as I have shown above.

Animal vaccination is too efficient a safeguard agraiust a loathsome disease, to have its good name injured by ignorance or knavery. The remedy is in the liands of physicians. They should inform themselves of the source of supply of the virus they use, and if abuses arise, should denounce them fearlessly, and not leave the disagreeable task to persons, whose pecuniary interest in the matter, renders their motives liable to misconstruction and wilful misrepresentation.

\section{Wieporta of Sorietieg.}

\section{MASSACHUSETTS MEDICAL SOCIETY, SUFFOLK DISTRICT. \\ SECTION FOR CLINICAL MEDICINE, PATHOI- OGY AND HYGIENE.}

ALBERT N. BLODGETT, M.D., SECRETARY.

Novenber 11 th, 1885. Meeting called to order at 8 o'clock, Dr. F. I. KNIGHT in the Chair. The records of the last meeting were read in summary and approved. There being no incidental business, the Chairman announced the first paper by Dr. S. C. MARTIN, of Roxbury, entitled

THE INOCULATION, PROPAGATION, AND PRESERVATION OF THE VIRUS OF ANIMAL VACCINE. WITH A DESCRIPTION OF THE APPEARANCES OF KINE POX, AND DEMONSTRATION OF THE VACCINE VESICLE UPON HEIFERS. ${ }^{1}$

The essay was attentively listened to by a very large audience, who warmly applauded the various recommendations for securing the purity of the vaccine sup$\mathrm{ply}$, and for a proper professional and financial system of conducting the business element connected with the propagation of vaccine virus. Upon a large and heavy oaken table in front of the audience was a living heifer about eighteen months old, and weighing alout six hundred pounds. The animal had been inoculated some days previously with three separate and distinct stocks or varieties of vaccine derived from three independent and widely separated sources, by the discovery of the vaccine disease in so-called "spontaneous" development in a single animal at each place. The heifer had been inoculated at about seventy-five separate points, and presented a large

1 Published page 560 of the Journal. number of well-formed vesicles, from which lymph was taken and ivory points were charged as is ordinarily done for the commercial supply.

The discussion was opened by Dr. S. W. Aввотt, of Wakefield, Chairman of the Massachusetts State Board of Health, who stated that he had been interested in the subject of vaccination as a protection from small-pox for many years. During the late Civil War, the source of the virus obtained for the army was from retrovaccination from the human species to the bovine, and from this source many thousands of soldiers acquired immunity from small-pox. Dr. Abbott entirely agrees with Dr. Martin in the necessity of the greatest care to preserve the purity of the bovine virus, and in the importance to the medical profession and to the entire people that the business of propagating vaccine virus should be intrusted only to such persons as are well known, responsible, and honest; besides possessing the necessary medical knowledge required for the safe and scrupulous management of so delicate a pathological process as is that of the vaccine disease in cattle.

The virus of vaccine is subject to many dangers evell when most carefully produced and most thoroughly protected. From the moment the lymph leaves the parent vesicle in which it was formed, it is undergoing a process of constant deterioration. Under some conditions, the best virus may become quite useless as a protection against the ravages of small-pox. I have known this to be the case in many parts of the United States, and to some persons, it has been the cause of a loss of confidence in the utility of vaccination as a prophylactic measure. Dr. Griffin, who is one of the pioneers of vaccination in the West, has observed the same failure in regard to protective power in the virus, which he traces to the following causes: First, the great distance from the source of the virus, which necessarily exposes this delicate material to many undesirable changes of temperature, and to a longer period of time between its production and the time of its use for protective inoculation. All virus is exceedingly perishable, and is constantly suffering from the moment it leaves the heifer. There is no doubt that ivory points are much to be preferred for the preservation of the virus, as they are smooth, shapely and convenient, and are, beyond question, the most useful carrier ever employed.

The use of crusts resulting from vaccine vesicles, or any portion of the dried scab, should be utterly abolished, and these substances should be entirely discarded in the protective and prophylactic treatment of variolous diseases. Many accidents have occurred from their use for purposes of vaccination, and not a few unfortunate complications, such as erysipelas, abscess, sloughing of the skin of the arm, and occasionally, septicæmia and death, have followed the introduction of the scab, or crust, or the so-called "cones," or parts of these substances into the human system. Of all these materials for inoculation, the "cones," which were formerly more extensively employed than now, are undoubtedly the most dangerous, as they were manufactured from scabs, crusts, and other products of the vaccine process, together with the frequent admixture of manure and other forms of filth and decomposition.

The proper time for preserving the virus for inoculation is at a period before the crust is formed. After this time, the contents of the vesicle become purulent, 